\title{
„WYSTAWA ZABYTKÓW Z CZASÓW KRÓLA JANA III I JEGO WIEKU" - WIELKIE PRZEDSIĘWZIĘCIE W RAMACH KRAKOWSKICH UROCZYSTOŚCI DWUSETNEJ ROCZNICY WIKTORII WIEDEŃSKIEJ
}

Sławomir A. Mróz

Muzeum Narodowe w Krakowie

\begin{abstract}
"AN EXHIBITION OF ARTEFACTS FROM THE TIME OF KING JOHN III AND HIS AGE:" A GREAT EVENT DURING THE CRACOW CELEBRATIONS OF THE $200^{\text {TH }}$ ANNIVERSARY OF THE VICTORY OF VIENNA
\end{abstract}

On September $12^{\text {th }}, 1883$, the $200^{\text {th }}$ anniversary of the Siege of Vienna was celebrated. In the Polish territories, which at that time were under the Austrian partition, the celebrations related to the jubilee of the victorious battle gained a special setting. In Cracow, one of the main events of the anniversarywas the "The Exhibition of Relics from the Time of King John III and His Age." Its opening night was connected with the opening of the National Museum to the public, initiated in October 1879. The Committee responsible for the exhibition was composed of distinguished representatives of the Polish (mainly Galician) scientific, political, cultural and artistic community. The article focuses on events related to the organization of the exhibition and presents its course and effects.

Key words: exhibition, National Museum in Cracow, Władysław Łuszczkiewicz, the Victory of Vienna.

Słowa kluczowe: wystawa, Kraków, Muzeum Narodowe w Krakowie, Władysław Łuszczkiewicz, wiktoria wiedeńska.

12 września 1683 roku pod murami Wiednia sprzymierzone wojska, dowodzone przez króla Jana III Sobieskiego, rozgromiły armię turecką wielkiego wezyra Kara Mustafy. Chrześcijańska Europa została uratowana, zajmujące ogromne terytorium 
imperium osmańskie przeszło do defensywy, a chwała polskiego oręża z biegiem lat stała się legendarna.

W 1883 roku dwusetną rocznicę wiktorii wiedeńskiej przyszło Polakom świętować w niewoli. Na próżno było szukać na mapie Starego Kontynentu Rzeczypospolitej, ponieważ została podzielona między trzech zaborców. Niestety nie wszędzie obchodzono tę rocznicę uroczyście. Na ziemiach polskich włączonych do Rosji, doświadczonych skutkami krwawo stłumionego powstania styczniowego, sytuacja w żaden sposób nie sprzyjała organizowaniu oficjalnej manifestacji patriotycznej taką wszak formę uzyskałyby obchody odsieczy Wiednia. Pamięć o wiktorii czczono więc prywatnie - w kościołach oraz dworach.

Odpowiednią patriotyczną rangę obchody zyskały natomiast w zaborze pruskim. Od 9 do 12 września zorganizowano kilkaset uroczystości w miastach, wsiach, dworach i pałacach ${ }^{1}$.

$\mathrm{Na}$ terenie cieszącej się wówczas autonomią Galicji uroczystości związane z jubileuszem odsieczy zyskały z kolei szczególną oprawę. Zaangażowana w nie została właściwie cała polska społeczność ${ }^{2}$. Obchody zorganizowano w co najmniej 146 miejscowościach. Choć była to liczba mniejsza niż w zaborze pruskim, to jednak program uroczystości był bardziej rozbudowany, ponadto frekwencja okazała się znacznie wyższa. Odbywały się nabożeństwa, organizowano specjalne akademie, zawierające także część artystyczną, oraz pochody z udziałem miejscowych organizacji, odsłaniano pamiątkowe tablice lub pomniki czy nadawano różnym obiektom imię Jana Sobieskiego ${ }^{3}$.

W 1883 roku Kraków liczył około 70000 mieszkańców i ustępował pod tym względem stolicy Galicji - Lwowowi - blisko dwukrotnie, ale dzięki całkowicie wówczas spolonizowanemu Uniwersytetowi Jagiellońskiemu (UJ) i Akademii Umiejętności (AU) oraz ożywieniu środowiska literacko-artystycznego zdobył już bezsprzecznie rangę centrum życia kulturalnego o ogólnopolskim zasięgu oddziaływania. Kraków do obchodów ku czci Jana III Sobieskiego był również predestynowany w sposób szczególny jako dawna stolica Polski, a wówczas stolica duchowa Polaków, pełna zabytków oraz pamiątek przeszłości narodowej ${ }^{4}$.

M. Rożek, Tradycja wiedeńska w Krakowie, Kraków 1983, s. 39-40.

2 P. Sierżęg a, Centralny Komitet Jubileuszowy w przygotowaniach obchodów 200. rocznicy odsieczy wiedeńskiej w Galicji [w:] Z przeszłości Europy Środkowowschodniej, red. J. Hoff, Rzeszów 2002, s. 76-77.

A. Galos, Obchody rocznicy odsieczy wiedeńskiej w Galicji w 1883 r., „Acta Universitatis Wratislaviensis" 1990, s. 134-136. Polacy obchodzili również dwusetną rocznicę odsieczy wiedeńskiej m. in. w Bytomiu, Wrocławiu, Wiedniu, Paryżu, Rapperswilu, a także w Stanach Zjednoczonych - w Chicago-Milwaukee, Detroit, Nowym Jorku i Louisville. Zob. A. Now ole ck i, Na pamiatkę 200-letniej rocznicy odsieczy Wiednia 1683 r. Uroczystości ku uczczeniu pamięci Jana III w ziemiach polskich i za granica, Kraków 1883, s. 52-56; Odsiecz wiedeńska 1683. Wystawa jubileuszowa w Zamku Królewskim na Wawelu w trzechsetlecie bitwy. Tło historyczne i materialy źródlowe, t. I, red. A. Franaszek, K. Kuczman, Kraków 1990, s. 22-24.

4 W. Bieńkowski, Rok 1883 w Krakowie (Uroczystości 200-lecia odsieczy Wiednia), „Rocznik Krakowski” 1987, s. 97-98. 
Po 200 latach od oswobodzenia Wiednia w Krakowie podjęto kilka przedsięwzięć mających na celu uczczenie tego wydarzenia. Należy jednak podkreślić, że w „duchowej stolicy Polaków" we wrześniu 1883 roku zrealizowano rozbudowany program - oprócz rocznicy wiktorii wiedeńskiej obchodzono także jubileusz 25-lecia pracy twórczej Jana Matejki, a poza tym zorganizowano wówczas pierwszy ogólnopolski zjazd literatów i artystów.

Już 8 września odbyła się uroczysta koronacja obrazu Matki Boskiej Łaskawej na Piasku. Oprócz najwyższych dostojników kościelnych w uroczystości brali udział reprezentanci władz miasta na czele z prezydentem Krakowa Ferdynandem Weiglem oraz kilkunastotysięczna rzesza wiernych przybyłych z różnych części dawnej Rzeczypospolitej. Wieczorem tego dnia miasto iluminowano, a na łuku bramy triumfalnej wzniesionej u wylotu ulicy Szewskiej oświetlono również przeźrocza, z których jedno przedstawiało Matkę Boską, a drugie Sobieskiego.

Oficjalne uroczystości w Krakowie trwały od 11 do 16 września 1883 roku i rozpoczęły się o godz. $9.00 \mathrm{w}$ katedrze wawelskiej mszą świętą za spokój duszy Sobieskiego oraz poległych pod Wiedniem. Do głównych przedsięwzięć zrealizowanych w tym czasie w ramach rocznicy odsieczy zaliczają się między innymi otwarcie „Wystawy zabytków z czasów króla Jana III i Jego wieku”, połączone z inauguracją Muzeum Narodowego (MNK), uroczystość ludowa polegająca na przemarszu reprezentantów powiatów Galicji z ulicy Floriańskiej do katedry w celu złożenia wieńców przy sarkofagu Sobieskiego, wystawienie sztuki Władysława L. Anczyca Jan III pod Wiedniem, uroczysta procesja z kościoła oo. Karmelitów na Piasku do katedry wawelskiej zakończona dziękczynnym nabożeństwem czy odsłonięcie płaskorzeźby autorstwa Piusa Welońskiego na jednej ze ścian kościoła Mariackiego oraz pomnika Sobieskiego w Ogrodzie Strzeleckim ${ }^{5}$.

Zgodnie z powyższym wernisaż „Wystawy zabytków z czasów króla Jana III i Jego wieku" połączony został z otwarciem dla społeczeństwa MNK, zainicjowanego w październiku 1879 roku przez artystę Henryka Siemiradzkiego, który przekazał do Sukiennic swój obraz Pochodnie Nerona.

Ta krakowska ekspozycja miała jeszcze większą wymowę, ponieważ w Wiedniu niemal równolegle zorganizowano wystawę z okazji obchodów 200-lecia oswobodzenia miasta. „Historische Ausstellung der Stadt Wien” trwała od 12 września do 4 listopada 1883 roku i dotyczyła oblężenia stolicy monarchii Habsburgów oraz późniejszych walk wojsk cesarskich z Turcją osmańską, zakończonych w 1699 roku pokojem w Karłowicach. Na pierwszy plan wysunięte zostały trofea tureckie. Wystawa cieszyła się olbrzymią frekwencją - zwiedziło ją ponad 160000 osób. Jej organizatorzy świadomie umniejszali rolę wojsk Rzeczypospolitej i Sobieskiego w kampanii wiedeńskiej, a na samej ekspozycji znalazło się zaledwie kilkanaście sobiescianów i poloników. Z tej przyczyny na łamach rodzimej prasy („Czasu”, „Gazety Narodowej” czy „Przeglądu Lwowskiego”) apelowano do Polaków o zrezygnowanie

Anonim, Koronacya cudami wstawionego obrazu Matki Boskiej na Piasku w Krakowie dnia 8 września 1883 roku, dodatek do nru 204 „Czasu”, 9 IX 1883, s. 1; A no nim, Program zbiorowy uroczystości dwuchsetnej rocznicy zwycięztwa króla Jana III pod Wiedniem oraz Jubileuszu Matejki, tudzież zjazdu literatów i artystów od d. 11 do d. 16 września 1883, dodatek do nru 204 „Czasu”, 9 IX 1883, s. 3. 
$\mathrm{z}$ udziału w przedsięwzięciu. Ewentualne wypożyczenie własnych obiektów związanych z odsieczą z roku 1683 na wystawę wiedeńską zostało zaś uznane za „zupełnie zbyteczne".

Celem pracy jest zrelacjonowanie organizacji „Wystawy zabytków z czasów króla Jana III i Jego wieku", przedstawienie jej przebiegu oraz zaprezentowanie skutków tego wydarzenia.

Tematy organizowania MNK w latach 1879-1883 czy gromadzenia pierwszych zbiorów wymagają odrębnych pogłębionych badań.

\section{$* * *$}

Koncepcja zorganizowania w Krakowie wystawy pamiątek historycznych związanych z osobą króla Jana III Sobieskiego zrodziła się przy okazji jubileuszu pracy twórczej Józefa I. Kraszewskiego w 1879 roku. Pomysłodawcą był znany fotograf, radny miejski i inicjator wielu przedsięwzięć kulturalnych Walery Rzewuski. Jego starania poparła ks. Zuzanna Czartoryska, żona ks. Marcelego Czartoryskiego, ówczesnego prezesa Towarzystwa Przyjaciół Sztuk Pięknych w Krakowie (TPSP), która podjęła działania mające na celu realizację zamierzenia Rzewuskiego. Pierwotnie zakładano, że zawiązany dzięki zabiegom Czartoryskiej prywatny komitet otworzy ekspozycję w rocznicę bitwy pod Wiedniem 12 września 1880 roku$^{8}$. W skład tegoż komitetu weszli między innymi: prezydent Krakowa Mikołaj Zyblikiewicz (jako przewodniczący), Józef Szujski, Stanisław Tarnowski, Fryderyk Zoll i Władysław Łuszczkiewicz. Ewentualny dochód z wystawy miał zostać przeznaczony na tworzące się MNK oraz na internat dla kandydatów do nauczycielskich szkół ludowych w Krakowie.

W roku 1880 komitet nie mógł jednak zrealizować założonego przedsięwzięcia pomimo wystosowania odezwy skierowanej do społeczeństwa z apelem o użyczenie obiektów i podjęcia decyzji przez Wydział Krajowy o przyznaniu subwencji w wysokości 1000 złotych austriackich ${ }^{9}$. Z biegiem czasu komitet został zreorganizowany oraz uzupełniony o nowych członków. Na jego czele stanął ks. Aleksander Czartoryski.

9 listopada 1882 roku Zoll, w imieniu całego wyżej wymienionego gremium, wystosował do rady miasta pismo, w którym zaproponowano, by Komisja Jubileuszu Sobieskiego odpowiedzialna za krakowskie uroczystości związane ze zbliżającą się rocznicą 200-lecia odsieczy wiedeńskiej podjęła wraz z komitetem wspólne działania na rzecz zorganizowania wystawy. Zgodnie z treścią listu pierwotny cel

6 Anonim, Dwie wystawy na dwóchsetletni obchód obrony Wiednia, „Czas”, 13 III 1883, nr 58, s. 3; Odsiecz wiedeńska 1683. Wystawa jubileuszowa..., s. 17-21; P. Sierżęg a, Obchody 200. rocznicy odsieczy wiedeńskiej w Galicji (1883 r.), Rzeszów 2002, s. 19-24; Anonim, Schluss der historischen Ausstellung, „Neue Freie Presse”, 5 XI 1883, nr 6894, s. 1.

7 A. Kłobukowski, Przyp. red., „Czas”, 21 XI 1883, nr 265, s. 2; A nonim, Rozmaitości z literatury, sztuki i życia społecznego, „Tygodnik Illustrowany”, 1 XII 1883, nr 48, s. 361.

8 C. Bąk-Koczarska, Rada miejska organizatorem obchodu 200-lecia odsieczy Wiednia w Krakowie, „Krzysztofory. Zeszyty Naukowe Muzeum Historycznego Miasta Krakowa” 1982, z. 9, s. 38.

9 P. Sierżęg a, Centralny Komitet Jubileuszowy..., s. 47-48. 
wystawy uległ zmianie i ekspozycja, ostatecznie urządzona w 1883 roku, zmieniła swój lokalny charakter - miała się stać „prawdziwą ucztą narodową”. Podjęcie wspólnych działań przez komitet i komisję uznano za konieczne i argumentowano obopólnymi korzyściami. Podkreślano również chęć realizowania celów nie przez komitet prywatny, lecz ciało, które - działając pod egidą władz miasta - miałoby charakter reprezentacyjny. Problem finansowania wystawy miał zaś być rozwiązany dzięki udzieleniu wsparcia z funduszy miejskich, które planowano zwrócić z uzyskanego dochodu ${ }^{10}$.

Rada miasta przyjęła propozycję. Zgodnie z uchwałą z 19 stycznia 1883 roku prywatny komitet został połączony z miejską Komisją Jubileuszową i tworzył odtąd osobny wydział odpowiedzialny za zrealizowanie przedsięwzięcia. Ponadto na styczniowym posiedzeniu Michał Bobrzyński przedstawił propozycję przebiegu planowanych uroczystości jubileuszowych, a otwarcie wystawy zaplanował na 11 września, czyli „W wilię rocznicy”. Podano także do wiadomości decyzję rady miasta, by na zorganizowanie wystawy przeznaczyć w formie pożyczki 2000 złotych austriackich $^{11}$. Kwota ta była więc dwukrotnie wyższa od pierwotnie planowanej subwencji Wydziału Krajowego.

Komitet wystawy zabytków z epoki Jana III (dalej: Komitet) składał się z 29 osób $^{12}$. Należeli do niego: prezydent Krakowa Ferdynand Weigel jako przewodniczący; wiceprezydent Stefan Muczkowski, prawnik, prof. UJ Ferdynand Zoll i właściciel ziemski (ojciec Marcelego, teść Zuzanny) ks. Aleksander Czartoryski jako zastępcy; sekretarz TPSP Piotr Umiński jako sekretarz Komitetu oraz członkowie: prezes AU, prof. Józef Majer; polityk, prof. historii literatury UJ Stanisław Tarnowski; prof. pierwszej katedry archeologii UJ Józef Łepkowski; prof. pierwszej katedry historii sztuki UJ Marian Sokołowski; przewodniczący Komisji Historii Sztuki AU (od lipca 1883 r. pierwszy dyrektor MNK), prof. Władysław Łuszczkiewicz; historyk, prawnik i polityk, prof. UJ Michał Bobrzyński; prawnik, prof. UJ Maksymilian Zatorski; sekretarz Komisji Historii Sztuki AU Stanisław Tomkowicz; polityk, członek Komisji Historii Sztuki AU Paweł Popiel; członek Komisji Archeologicznej AU (od września 1883 r. pierwszy kustosz MNK) Teodor Nieczuja-Ziemięcki; polityk, założyciel Muzeum Książąt Czartoryskich w Krakowie (dalej: MCz.), ks. Władysław Czartoryski; polityk (brat Aleksandra), ks. Konstanty Czartoryski; politycy, bracia Artur i Andrzej Potoccy; właściciel ziemski, współtwórca Towarzystwa Naukowego w Toruniu Adam Sierakowski; historyk, archiwista i współwłaściciel drukarni „Czasu” Franciszek Kluczycki; historyk (siostrzeniec Tarnowskiego) Jerzy

\footnotetext{
${ }^{10}$ Archiwum Narodowe w Krakowie (dalej: ANKr), sygn. 29/576/43, Do Wysokiej Rady Miasta Krakowa, 9 XI 1882, s. 1803-1809.

${ }^{11}$ ANKr, sygn. 29/576/43, Protokół obrad Komisyi jubileuszu Sobieskiego z dnia 19 I 1883, s. $1347-1350$.

12 W nrze 73 z 31 III 1883 r. krakowskiego „Czasu” wymienionych jest 28 członków Komitetu, ale w opracowaniu Łuszczkiewicza dotyczącym wystawy (napisanym w trakcie jej trwania i wydanym jeszcze w 1883 r.) wśród członków znajduje się także Maksymilian Zatorski. Zob. A noni m, Sobiesciana, „Czas”, 31 III 1883, nr 73, s. 2; W. Łuszczkiewicz, Z wystawy starożytności z czasów Sobieskiego w Sukiennicach. Wrażenia i uwagi, Kraków 1883, s. V-VI.
} 
Mycielski; artysta malarz Juliusz Kossak; ksiądz Ignacy Polkowski; działacz kulturalny Zygmunt Cieszkowski oraz radni miasta Krakowa - Walery Rzewuski, Teodor Baranowski, Karol Zaremba i ksiądz Teofil Midowicz ${ }^{13}$.

Podczas analizy listy członków Komitetu nasuwa się oczywisty wniosek: wydział odpowiedzialny za organizację wystawy składał się z wybitnych osobistości, przedstawicieli polskiego (głównie ówczesnej Galicji) środowiska naukowego, politycznego, kulturalnego czy artystycznego ${ }^{14}$. Warto także zaznaczyć, że dziewięć spośród wymienionych powyżej osób weszło do grona pierwszego Komitetu MNK, najważniejszego organu zarządzającego tą instytucją ${ }^{15}$.

Ponadto uwagę zwraca fakt, że wśród członków znajdowali się czołowi reprezentanci krakowskich konserwatystów - stańczyków (np. Tarnowski, Bobrzyński czy Popiel) - i osoby ściśle z tym środowiskiem współpracujące (np. Mycielski czy Andrzej i Artur Potoccy) ${ }^{16}$.

W marcu 1883 roku rozpoczęto akcję wysyłania oficjalnych listów z prośbą o wypożyczenie posiadanych zbiorów na organizowaną wystawę. Zachęcano także do tych działań za pośrednictwem prasy. Korespondencja, oprócz treści oficjalnej, zawierała załączniki ze szczegółowymi wykazami zbiorów zakwalifikowanych na planowaną ekspozycję. W zaproszeniach zapewniano również, że zadbano o środki bezpieczeństwa w celu ochrony obiektów. Adresaci proszeni byli o poinformowanie Komitetu drogą pocztową o podjętej decyzji do 1 czerwca oraz o przysłanie zapakowanych obiektów do 10 sierpnia. Otwarcie wystawy zaplanowano na 11 września, a jej finisaż na koniec października. Proszono ponadto, by osoby posiadające obiekty z XVII wieku same zgłaszały ten fakt, wysyłając list na ręce prezydenta Krakowa. Dzięki temu Komitet mógł zgromadzić możliwie najwięcej informacji na temat zbiorów, które uświetniłyby ekspozycję. Równie istotne było wyeliminowanie pomyłek i pominięć, które przy organizacji przedsięwzięcia tej skali mogły się wydarzyćc ${ }^{17}$.

13 W Polskim Stowniku Biograficznym znaleźć można biogramy większości z wymienionych osób. Ponadto dostępne są monografie naukowe poświęcone np. Stanisławowi Tarnowskiemu (J. Dybiec, Stanisław Tarnowski - autorytet, polityk, uczony [głos w dyskusji], Kraków 1999), Michałowi Bobrzyńskiemu (W. Łazuga, Ostatni stańczyk. Michat Bobrzyński - portret konserwatysty, Toruń 2005) czy Juliuszowi Kossakowi (K. O1szański, Juliusz Kossak, Kraków 2000).

${ }^{14} \mathrm{Z}$ wyjątkiem Sierakowskiego, którego działalność skupiała się głównie na terenach zaboru pruskiego. Zob. A. Chodubski, Sierakowski Adam (1846-1912), PSB, t. XXXVII, Warszawa-Kraków 1996-1997, s. 254-255.

${ }^{15}$ D. Błoń ska, S.A. Mróz, Na przełomie starych i nowych czasów. Muzeum Narodowe w Krakowie w latach 1900-1901, „Res Gestae. Czasopismo Historyczne” 2016, t. 3, s. 97-98; Narodziny Muzeum. Ważniejsze daty w stuletnich dziejach Muzeum Narodowego w Krakowie, red. F. S tolot, Kraków 1979, s. $16-17$.

${ }_{16}$ J. Bieniarzówna, J.M. Małecki, Dzieje Krakowa. Kraków w latach 1796-1918, t. 3, Kraków 1979, s. 245-252; A. Kosicka-Pajewska, Zachowawcza myśl polityczna w Galicji w latach 18641914, Poznań 2002; S. Pijaj, Między polskim patriotyzmem a habsburskim lojalizmem. Polacy wobec przemian ustrojowych monarchii habsburskiej (1866-1871), Kraków 2003.

${ }_{17}$ Archiwum Muzeum Narodowego w Krakowie (dalej: Arch. MNK), sygn. 94/17, Wystawa zabytków z czasów króla Jana III i Jego wieku. Korespondencja dotycząca wypożyczeń, Zaproszenie Komitetu wystawowego. 
$\mathrm{Z}$ jednej strony, by nie uszczuplać funduszu przeznaczonego na wystawę, $\mathrm{z}$ drugiej zaś, by nie obciążać samych zainteresowanych, prezydent Weigel podjął energiczne starania o uzyskanie zwolnienia - w całości lub częściowo - z cła i opłat transportowych od obiektów przysyłanych do Krakowa. Działania zostały zakończone sukcesem. Bezpłatny przewóz wszelkiego rodzaju eksponatów między 1 sierpnia a końcem października 1883 roku ofiarowały dyrekcje Galicyjskiej Kolei Karola Ludwika i Kolei Czerniowieckiej, a od 1 sierpnia do 15 listopada - Pierwszej Węgiersko-Galicyjskiej Kolei Żelaznej, Naddniestrzańskiej, Tarnowsko-Leluchowskiej oraz Arcyksięcia Albrechta. Podkreślić należy, że rozporządzenia obejmowały także transport powrotny obiektów. Ponadto Ministerstwo Skarbu zezwoliło na zwolnienie z cła wszystkich eksponatów przysyłanych spoza monarchii ${ }^{18}$.

Dodatkowo członkowie Komitetu zwrócili się z prośbą do biskupa krakowskiego Albina Dunajewskiego, by zezwolił na prowadzenie poszukiwań obiektów będących w posiadaniu krakowskich kościołów i klasztorów. Również ta inicjatywa spotkała się z życzliwym odbiorem, a na osobę odpowiedzialną za przeprowadzenie stosownych działań biskup wyznaczył członka Komitetu - księdza Polkowskiego, łączącego w sobie „charakter duchowny z zamiłowaniem dzieł sztuki”"19.

Już od początku kwietnia rozpoczęła się intensywna wymiana korespondencji między członkami Komitetu a właścicielami obiektów. Również prośby zamieszczone na łamach prasy o informowanie drogą pocztową o posiadaniu i gotowości wypożyczenia na wystawę własnych zbiorów przyniosły pozytywny skutek ${ }^{20}$.

Komitet z wyprzedzeniem podjął także kroki mające wyeliminować ewentualny problem niewypożyczenia obiektów przez osoby prywatne z Krakowa z powodu ich absencji w mieście w okresie letnich upałów. Na łamach prasy proszono, by właściciele eksponatów przed planowanym urlopem upoważnili wskazane przez siebie osoby do wysłania obiektów w czasie ich nieobecności ${ }^{21}$.

Wymiana korespondencji między Komitetem a osobami prywatnymi i instytucjami (w tym również kościelnymi obrządku łacińskiego) w Galicji wydaje się oczywista. Organizatorzy wystawy nie ograniczyli się jednak do prób pozyskania obiektów od mieszkańców (lub instytucji) tylko zaboru austriackiego. Korespondencja adresowana była między innymi do: dyrekcji pałacu Schleissheim (Bawaria), dyrekcji muzeum miejskiego w Brnie (Morawy), ks. Baltazara Odescalchiego (Rzym), księdza Jana I. Korytkowskiego (Gniezno) czy Emeryka Hutten-Czapskiego (Stańków) ${ }^{22}$.

${ }^{18}$ C. Bąk-Koczarska, op. cit., s. 45; F. Zo1l, Sobiesciana, „Czas”, 10 VII 1883, nr 153, s. 3; Anonim, Sobiesciana, „Czas”, 15 VII 1883, nr 158, s. 2; F. Zo11, Sobiesciana, „Czas”, 24 VII 1883, nr 165, s. 3. Na bezpłatny wyłącznie transport powrotny obiektów pozwoliła natomiast dyrekcja Kolei Północnej Cesarza Ferdynanda. Zob. F. Zo11, Sobiesciana, „Czas”, 1 VIII 1883, nr 172, s. 3.

19 Anonim, Sobiesciana, „Czas”, 20 IV 1883, nr 89, s. 3.

${ }^{20}$ Przykładowo: Anonim, Sobiesciana, „Czas”, 12 IV 1883, nr 82, s. 2; A nonim, Sobiesciana, „Czas”, 20 IV 1883, nr 89, s. 2; An onim, Sobiesciana, „Czas”, 20 V 1883, nr 112, s. 3.

${ }^{21}$ Anonim, Sobiesciana, „Czas”, 10 V 1883, nr 104, s. 4.

${ }_{22}$ Anonim, Sobiesciana, „Czas”, 20 V 1883, nr 112, s. 3; Anonim, Sobiesciana, „Czas”, 1 VI 1883, nr 121, s. 3; Anonim, Sobiesciana, „Czas”, 26 VII 1883, nr 167, s. 3; Anonim, Sobiesciana, „Czas”, 4 VIII 1883, nr 175, s. 2. 
Pod koniec czerwca na łamach „Czasu” zostało opublikowane ogłoszenie Komitetu zawierające dwie ważne informacje. Pierwsza z nich to prośba organizatorów, by właściciele - przesyłając swoje obiekty do Krakowa - kierowali je na adres gmachu Kasy Oszczędności (ul. Szpitalna), gdzie od 1 lipca miało funkcjonować Biuro Wystawy. Z tego miejsca dopiero zbiory miały być transportowane do Su-

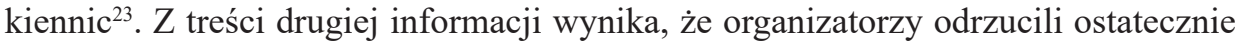
pierwotną koncepcję wystawy, która zakładała ograniczenie się tylko do pamiątek po Sobieskim. W rezultacie ekspozycję miały tworzyć obiekty związane z dziejami Rzeczypospolitej XVII wieku, „rzucające światło na ówczesny stan sztuki, przemysłu, wykształcenia umysłowego, życia domowego, obyczajów, sztuki wojennej” itd. By założenie mogło zostać zrealizowane, oczekiwano na przysłanie do Krakowa bardzo różnorodnych obiektów ${ }^{24}$.

Upływ czasu przewidzianego na przygotowania do wystawy zweryfikował pierwotne założenia członków Komitetu, dlatego też postanowiono, że ostatecznym terminem przysyłania obiektów do Krakowa będzie koniec sierpnia ${ }^{25}$, ale i te założenia pozostały w zderzeniu z rzeczywistością jedynie „na papierze”. Faktem jest, że transport zbiorów nabrał tempa w sierpniu, lecz bardzo wiele obiektów dotarło „pod Wawel" w pierwszym, a nawet drugim tygodniu września, czyli tuż przed planowanym uroczystym otwarciem wystawy. Dość powiedzieć, że w ostatnich dniach sierpnia zgromadzono około 400 obiektów, a po kilku dniach ich liczba przekroczyła $1300^{26}$. Ponadto należy podkreślić, że eksponaty docierały do Krakowa również w trakcie trwania wystawy, a ostatnie przysłane obiekty znalazły się w Sukiennicach dopiero w listopadzie ${ }^{27}$.

Zgodnie z ogłoszonymi drukiem pracami, których autorami byli organizatorzy wystawy, do najważniejszych i najdrogocenniejszych obiektów eksponowanych w Sukiennicach należały między innymi: obraz Matki Bożej (w typie loretańskiej); portret Sobieskiego w karacenie z delią; popiersie z brązu „zwycięzcy spod Wiednia"; marmurowa płaskorzeźba z wizerunkiem papieża Innocentego XI, za którego pontyfikatu doszło do odsieczy; karabela Sobieskiego; karacena i głownia od szabli hetmana Stanisława Jabłonowskiego; głownia od karabeli i strzemię Kara Mustafy;

${ }^{23}$ Sukiennice i gmach ówczesnej Kasy Oszczędności Miasta Krakowa (dzisiejsza siedziba jednego z oddziałów Banku Pekao S.A.) dzieli kilkaset metrów.

${ }^{24}$ Anonim, Sobiesciana, „Czas”, 29 VI 1883, nr 145, s. 2-3.

${ }^{25}$ F. Weigel, Wystawa zabytków z epoki Sobieskiego w Krakowie 1883 r., „Czas”, 2 VIII 1883, nr 173, s. 2.

${ }^{26}$ W. Łuszczkiewicz, J. Mycielski, I. Polkowski, P. Umiński, Katalog wystawy zabytków z czasów króla Jana III i Jego wieku, Kraków 1883, s. III-IV. Potwierdzeniem tego stanu rzeczy są także protokoły odbioru obiektów, np. : Arch. MNK, sygn. 94/18, Wystawa zabytków z czasów króla Jana III i Jego wieku. Protokoły wypożyczeń. Spisy eksponatów, Protokół odbioru obiektów należących do Andrzeja Lubomirskiego z 27 VIII 1883; Protokół odbioru obiektów należących do Wandy Jabłonowskiej z 3 IX 1883; Protokół odbioru obiektów należących do Jana Tadeusza Lubomirskiego z 10 IX 1883.

${ }^{27}$ C. Bąk-Koczarska, op. cit., s. 49; Anonim, Wiadomości artystyczne, literackie i naukowe, „Czas”, 14 XI 1883, nr 259, s. 2. 
zbroje husarskie; rząd koński należący do króla Michała Korybuta Wiśniowieckiego; jedna z armat zamku w Stanisławowie; aksamitny orientalny kobierzec przedstawiający ogród ze zwierzętami; gobeliny: z wyobrażeniem narodzenia Adonisa oraz bitwy Aleksandra Wielkiego nad Granikiem; czarna, aksamitna, haftowana złotem i srebrem kapa kościelna; hebanowy sepecik z herbami Rzeczypospolitej i Wazów; brązowy, pozłacany zegar stołowy i srebrna, pozłacana taca, przedstawiająca kąpiel bogini Diany ${ }^{28}$.

Pierwszy spośród wymienionych w powyższym akapicie obiektów - obraz Matki Bożej, będący własnością ks. Antoniego Radziwiłła - uznawany był za „klejnot” wystawy. Według tradycji dzieło to zostało znalezione podczas kampanii wojennej w 1683 roku w ruinach wsi Wishau pod Wiedniem, następnie z woli królewskiej przekazane do kaplicy w Żółkwi. Potem stało się ono własnością rodziny Radziwiłłów. Odebrawszy od Komitetu zaproszenie na urządzaną wystawę, wymieniony wyżej właściciel polecił przesłać z Berlina do Krakowa ramy tegoż dzieła, obraz dostarczył natomiast osobiście na początku sierpnia 1883 roku $^{29}$.

Organizatorom wystawy nie dane było niestety eksponować wspaniałej karaceny, która zgodnie z tradycją miała należeć do Sobieskiego - obiekt ten, stanowiący własność muzeum drezdeńskiego, wypożyczono do Wiednia. W związku z tym organizatorzy dołożyli starań, by w Sukiennicach można ją było zobaczyć na fotografii i rysunku ${ }^{30}$.

Nie udało się także pozyskać obrazu Lisowczyk (inna nazwa: Jeździec polski) Rembrandta van Rijna, który należał wówczas do Jana Dzierżysława Tarnowskiego i stanowił ozdobę jego pałacu w Dzikowie. Mimo że Tarnowski wypożyczył do Krakowa inne obrazy oraz broń palną, to nie wyraził zgody, by dzieło wybitnego holenderskiego artysty uświetniło ekspozycję, argumentując swą decyzję następująco: „Lisowczyka jako klejnot tutejszej galeryi niechętnie ruszam z miejsca, obawiając się uszkodzenia, które przy wielkiej odległości od kolei i niezbędnem przeładowywaniu, łatwo jest możliwe" ${ }^{\prime 1}$.

${ }^{28}$ W. Łuszczkiewicz, J. Mycielski, I. Polkowski, P. Umiński, op. cit.; W. Łuszczkiewicz, Z wystawy starożytności...; F. Kluczycki, W. Łuszczkiewicz, J. Mycielski, I. Polkowski, S. Tomkowicz, P. Umiński, T. Ziemięcki, Zabytki XVII wieku. Wystawa jubileuszowa Jana III w Krakowie 1883, Kraków 1884; M. Sokołow ski, Wystawa zabytków z czasów Jana III w Sukiennicach krakowskich w roku 1883, Kraków 1884.

${ }^{29}$ Anonim, Sobiesciana, „Czas”, 21 VI 1883, nr 138, s. 2; I. Polkowski, Sobiesciana, „Czas”, 13 VII 1883, nr 156, s. 2-3; Ano nim, Sobiesciana, „Czas”, 10 VIII 1883, nr 180, s. 3; Z upoważnienia księcia Antoniego Radziwiłła z Komitetem korespondencyjnie kontaktował się Feliks Podlewski: Arch. MNK, sygn. 94/17, Korespondencja F. Podlewskiego z Komitetem z 6 VI 1883; Korespondencja F. Podlewskiego z Komitetem z 25 VII 1883; Korespondencja F. Podlewskiego z Komitetem z 3 VIII 1883.

${ }^{30}$ W. Łuszczkiewicz, Z wystawy starożytności..., s. 43; J. Łoski, Jan Sobieski, jego rodzina, towarzysze broni $i$ wspótczesne zabytki, Warszawa 1883, s. 68.

${ }^{31}$ Arch. MNK, sygn. 94/17, Korespondencja Jana D. Tarnowskiego z Komitetem z 1 VIII 1883; W. Łuszczkiewicz, J. Mycielski, I. Polkowski, P. Umiński, op. cit., s. 11, 27, 44. Dzisiaj obraz Lisowczyk Rembrandta należy do zbiorów Frick Collection w Nowym Jorku. M. Walicki, Rembrandt w Polsce, „Biuletyn Historii Sztuki”1956, R. XVIII, nr 3, s. 328-329. 
Eksponatów do Sukiennic nie wypożyczyli również Aleksandra Potocka (Wilanów) oraz właściciel znakomitych zbiorów, założyciel MCz. i zarazem członek Komitetu, ks. Władysław Czartoryski ${ }^{32}$. Pomimo starań poszczególnych osób ze wspomnianego gremium, Czartoryski zaledwie kilka dni przed otwarciem ekspozycji w Sukiennicach zezwolił jedynie na - w razie wyrażenia chęci przez Jerzego Moszyńskiego - wypożyczenie obiektów ze stanowiącego depozyt w MCz. zbiorów rodziny Moszyńskich. Na koniec decyzją tego ostatniego tak się jednak nie stało. Ponadto $\mathrm{w}$ tym miejscu należy podkreślić, że ówcześni pracownicy MCz. (w tym dyrektor Łepkowski - również członek Komitetu) w korespondencji skierowanej do Czartoryskiego wyrażali sprzeciw wobec ewentualnego wypożyczenia jego obiektów, a w przygotowywanej wystawie w Sukiennicach upatrywali także możliwość nabycia nowych eksponatów do instytucji, którą reprezentowali33 ${ }^{33}$.

Ze względu na organizowanie własnych uroczystości związanych z rocznicą odsieczy wiedeńskiej negatywną decyzję podjęło również Muzeum Narodowe w Rapperswilu. Oto fragment korespondencji Władysława Platera z jednym z członków Komitetu z maja 1883 roku: „Obchód tej uroczystości w Zamku Rapperswyl nie dozwala Zarządowi muzealnemu pozbywać się nawet chwilowo pamiątek po Sobieskim; bez tej przeszkody przesłane by rychło zostały pod adresem dostojnego Pana Prezesa. Nikt bardziej od nas nie czuje potrzeby narodowej solidarności w epoce tak bolesnej dla Polski”"34.

$* * *$

Zgodnie z programem krakowskich uroczystości 200-lecia wiktorii wiedeńskiej, we wtorek 11 września 1883 roku o godzinie 11.00 Zyblikiewicz, marszałek Sejmu Krajowego, w górnych salach Sukiennic otworzył „Wystawę zabytków z czasów króla Jana III i Jego wieku". W swoim przemówieniu podkreślił znaczenie XVII-wiecznej Rzeczypospolitej jako przedmurza chrześcijaństwa, a skupiając się na nagromadzonych na wystawie obiektach, powiedział: ,[...] niech nam one uprzytomnią dawną naszą świetność, wszakże nie dla marnej przechwałki tylko, lecz dla pokrzepienia ducha, abyśmy wytrwać mogli w tem, co nas zdolnymi czyniło do zaważenia na szali losów narodów, a wyzbyli się błędów, które nam nasz upadek zgotowały”35.

Po jego słowach, które wywołały oklaski wśród zgromadzonej publiczności, przemowę wygłosił Zoll - zastępca przewodniczącego Komitetu. Następnie w sali zwanej

${ }^{32}$ M. Rożek, Zwycięstwo Jana III Sobieskiego pod Wiedniem. Echa wiktorii, Kraków 2008, s. 99; T. Zi emięcki, Wystawa zabytków z epoki króla Jana III-go i jego wieku, „Czas”, 4 X 1883, nr 225, s. 3.

${ }^{33}$ Biblioteka Książąt Czartoryskich w Krakowie (dalej: BCz.), sygn. 7312 IV, Korespondencja J. Łepkowskiego do W. Czartoryskiego z 19 II 1883; Korespondencja J. Łepkowskiego i L. Bentkowskiego do W. Czartoryskiego z 15 III 1883; Korespondencja J. Łepkowskiego do W. Czartoryskiego z 8 IV 1883, Korespondencja J. Łepkowskiego i L. Bentkowskiego do W. Czartoryskiego z 15 IV 1883; Korespondencja J. Łepkowskiego do W. Czartoryskiego z 8 VIII 1883; Korespondencja L. Bentkowskiego do W. Czartoryskiego z 6 IX 1883; Korespondencja L. Bentkowskiego do W. Czartoryskiego z 10 IX 1883; Korespondencja J. Łepkowskiego do W. Czartoryskiego z 3 X 1883; Korespondencja J. Łepkowskiego do W. Czartoryskiego z 28 X 1883.

${ }_{34}$ Arch. MNK, sygn. 94/17, Korespondencja W. Platera z Komitetem z 19 V 1883.

35 Józefa Czecha Kalendarz Krakowski na rok 1884, Kraków 1884, s. 89-90. 
Langierówką dokonano inauguracji MNK. Dzięki temu zwiedzającym udostępniono także zbiory tej instytucji gromadzone od 1879 roku, jak również kartony do witraży w kaplicy Przezdzieckich w kościele oo. Dominikanów w Krakowie (przekazane na ręce prezydenta Józefa Dietla jako dar dla przyszłego muzeum) oraz kolekcję kamei i gemm (wówczas jeszcze własność prywatna Konstantego Schmidta-Ciążyńskiego). Po dokonaniu aktu poświęcenia muzeum przez biskupa Dunajewskiego głos zabrali prezydent Weigel oraz pierwszy dyrektor instytucji Łuszczkiewicz. Tym samym MNK oficjalnie otworzyło swoje podwoje społeczeństwu ${ }^{36}$.

„Wystawa zabytków z czasów króla Jana III i Jego wieku” prezentowała się imponująco. Tuż przy wejściu do Sukiennic zwiedzający mogli się cieszyć widokiem namiotu tureckiego i armat. Potem udawali się spiralnymi schodami na piętro budynku. Nad drzwiami do sali głównej, w której urządzono większą część ekspozycji, wisiał „barwny herb Polski z godłem Janiny”. Wchodząc do środka, zwiedzający mogli podziwiać wystawę w całym jej przepychu i majestacie.

Wielka sala Sukiennic olbrzymiej długości, tak zwana balowa, i sąsiednia salka od ulicy Brackiej przeznaczone na wystawę, zapełnione są od góry do dołu pamiątkami przeszłości. Ściany pokryte portretami znakomitych osób pędzla XVII wieku, wypełnione makatami i gobelinami są tłem, na którem rozłożyły się całe szeregi stojących u spodu sprzętów domowych, uzbrojeń i tych tysiąca przedmiotów, jakimi dom pański, kościół, obozowe leże itp. się stroiły. Jako główne sanktuaryum w wielkiej Sali znajduje się popiersie bronzowe króla Jana III na wzniesieniu z oparciem i tłem z namiotów tureckich, z całym szeregiem trofeów wiedeńskich jak szabli, zbroi itp. Środkiem sali szeregi witryn zajmują kosztowne drobne przedmioty, a tych jest bez miary; w rogach cztery zaszklone szafy wielkie mieszczą na pułkach również cenne przedmioty. Salka mniejsza przeznaczona głównie na pomieszczenie cudownego obrazka Najś. Panny znalezionego pod Wiedniem i prowadzącego do zwycięztwa króla Jana III, ma charakter obozowy. Jakoż i sam obraz jest w namiocie strzeżony przez dwóch konnych husarzy, tu również rozpięte są dwa małe tureckie namioty. Ściany tej salki ubierają portrety i makaty ${ }^{37}$.

Na wystawie eksponowano łącznie około 2000 obiektów w tym: obrazy, relikwiarze, lichtarze, sztychy, zbroje, hełmy, tarcze, kopie, armaty, muszkiety, rusznice, pistolety, szable, karabele, pałasze, szpady, rapiery, sztylety, bagnety, koncerze, łuki tureckie i tatarskie, kusze, prochownice, rzędy końskie, chorągwie, proporce, buzdygany, namioty tureckie, ornaty, kobierce, makaty, stroje, wachlarze, zegary, pierścienie, różnego rodzaju numizmaty, meble, naczynia i sprzęty stołowe, wyroby z porcelany, instrumenty muzyczne, dokumenty rękopiśmienne czy starodruki ${ }^{38}$.

Warto w tym miejscu zaznaczyć, że na wystawę składały się niemal wyłącznie obiekty wypożyczone - tylko kilka eksponatów było własnością MNK: portret

${ }^{36}$ Anonim, Program zbiorowy uroczystości..., s. 4-5; An on im, Uroczystość dwuchsetletniej rocznicy zwycięstwa Jana III pod Wiedniem, „Czas”, 12 IX 1883, nr 206, s. 2-3; Anonim, Uroczystości krakowskie, „Gazeta Lwowska”, 12 IX 1883, nr 208, s. 2-3; W. Bieńkowski, op. cit., s. 109-110; M. Rożek, Tradycja wiedeńska ..., s. 45-46; A. Nowolecki, op. cit., s. 21-25.

${ }^{37}$ W. Luszczkiewicz, op. cit., s. 3-4; Wymienione w tymże fragmencie opracowania gabloty i szafy wykonał na potrzeby ekspozycji Zakład Wyrobów Stolarskich Romana Chmurskiego, za szyby odpowiedzialny był Skład Szyb Belgijskich i Listew na Ramy K. Grünwalda, roboty dokończył zaś szklarz Teodor Zajdzikowski; ANKr, sygn. 29/576/43, s. 1829-1837.

${ }^{38}$ W. Łuszczkiewicz, J. Mycielski, I. Polkowski, P. Umiński, op. cit. 
Sobieskiego (dar Oswalda Szymanowskiego ${ }^{39}$ ), zdobyty według tradycji pod Wiedniem czerwony płócienny namiot turecki oraz części karocy mającej należeć do wspomnianego wyżej króla (dary Józefa Drohojowskiego) ${ }^{40}$ i wykonany w Augsburgu kompas podróżny (dar niewymienionego niestety z imienia Paderewskiego ${ }^{41}$.

W sposobie urządzenia dwóch sal organizatorzy kierowali się znaną ówcześnie wystawiennictwu zasadą, zakładającą zapełnianie każdej wolnej przestrzeni obiektami ułożonymi w sposób przemyślany pod względem artystycznym. Dążyli równocześnie do wywołania określonych przeżyć emocjonalnych. W związku z tym większa sala skupiała obiekty, które miały gloryfikować zasługi Sobieskiego jako zwycięzcy, a zarazem zbawcy chrześcijaństwa. Na osi dłuższych ścian opisywanej sali, pokrytych tkaninami, gobelinami czy portretami (Jana III, jego rodziny, innych polskich władców oraz znakomitych osobistości XVII stulecia) dominowały celowo skomponowane i plastycznie wyodrębnione dekoracje, podkreślające treści ideowe zawarte w ekspozycji. Pośrodku ściany wschodniej na pierwszy plan wysuwało się popiersie Sobieskiego w wieńcu z liści dębowych, ustawione na podwyższeniu, znajdujące się „pod baldachimem" - namiotem tureckim - i otoczone trofeami wojennymi, bronią, jak również uzbrojeniem. To „sanktuarium” zamykały z dwóch stron bogate i zróżnicowane kolorystycznie czapraki, rzędy końskie i siodła. Naprzeciw popiersia, pośrodku ściany zachodniej, pośród portretów szczególnie odznaczała się marmurowa płaskorzeźba Innocentego XI, znajdująca się również w otoczeniu różnorodnej broni. Po bokach płaskorzeźby ustawiono ozdobne elementy oporządzenia jeździeckiego. Powyżej zawieszony był imponujących rozmiarów gobelin przedstawiający bitwę Aleksandra nad Granikiem, zawierający wyraźną aluzję do rycerskiego bohaterstwa oraz gotowości do poświęceń. Ekspozycję uzupełniały rozłożone wzdłuż ścian, wyszukane, bogato rzeźbione meble, a w jej narożnikach oraz pośrodku - szafy i witryny, w których zgromadzono drobniejsze przedmioty.

Mniejsza sala stwarzała nastrój obozu wojennego. Znajdował się w niej „klejnot” wystawy - obraz Matki Bożej ustawiony w namiocie tureckim pełniącym funkcję kaplicy polowej, która z kolei była „strzeżona” przy wejściu przez dwa manekiny konnych husarzy. „Kaplica” została celowo usytuowana na podłużnej osi obu sal, przyciągając już od wejścia wzrok zwiedzających. Na ścianach pomieszczenia eksponowane były portrety i makaty, a nastrój obozowy potęgowały dwa inne namioty tureckie. Światło docierające z okna w suficie dyskretnie przytłumiono zasłoną,

${ }^{39}$ Arch. MNK, sygn. 94/10, Inwentarz zbiorów (1879-1900), nr 75, s. 13; Arch. MNK, sygn. 94/17, Korespondencja K. Estreichera starszego z Komitetem z 15 VII 1883; Arch. MNK, sygn. 94/17, Korespondencja O. Szymanowskiego z Komitetem z 23 VII 1883; W. Łuszczkiewicz, J. Mycielski, I. Polkowski, P. Umiński, op. cit., s. 9.

${ }^{40}$ Arch. MNK, sygn. 94/10, nr 103-104, s. 20; W. Łuszczkiewicz, J. Mycielski, I. Polkowski, P. Umiński, op. cit., s. 88; Arch. MNK, sygn. 94/16, Dary (1879-1900), Korespondencja J. Drohojowskiego z M. Zyblikiewiczem z 28 XI1879; W. Łuszczkiewicz, op. cit., s. 50-51.

${ }^{41}$ Arch. MNK, sygn. 94/10, nr 115, s. 21; Arch. MNK, sygn. 94/7, Księga darów (1879-1894), nr 115, k. 15; W. Łuszczkiewicz, J. Mycielski, I. Polkowski, P. Umiński, op. cit., s. 218. 
a miejscu dodatkowo nadawał „mistycznego uroku” blask zawieszonej u stropu lampy ${ }^{42}$.

Autorem oprawy plastycznej i układu samej ekspozycji był artysta Weloński. Katalog wystawy opracowali wspólnie Łuszczkiewicz, Mycielski, Polkowski i Umiński. Wymienieni czterej członkowie Komitetu znajdowali się także - obok Sokołowskiego, Kluczyckiego, Tomkowicza i Ziemięckiego - w gronie autorów albumu z tekstem objaśniającym 41 tablic, dającym dobre pojęcie nie tylko o samych eksponatach, lecz także o sposobie ich pokazania. Trudu napisania bardzo ważnych opracowań, starannie wyjaśniających charakterystykę ekspozycji oraz podkreślających jej walory naukowe, podjęli się z kolei Łuszczkiewicz i Sokołowski ${ }^{43}$.W publikacji pierwszego dyrektora MNK znaleźć można dodatkowo interesujący fragment na temat poszczególnych obszarów działalności kilku członków Komitetu przy realizacji tego przedsięwzięcia:

Oddać na tem miejscu wypada należne uznanie i podziękę hr. Zygmuntowi Cieszkowskiemu, który nietylko nie szczędził trudu i fatygi, ale nadto własną ofiarnością pokrywał co naglejsze koszta i wydatki, panom Łuszczkiewiczowi, Tomkowiczowi, Sokołowskiemu i Ekscelencyi Popielowi, którzy mądrem swem zdaniem i radą i czynną pomocą, przyczynili się do umiejętnego urządzenia wystawy; panom dr. Zollowi i Rzewuskiemu, którzy wraz z prezydentem miasta dr. Weiglem wszystkie trudności usuwali, o wszystkie możliwe ułatwienia starali się i gwarancyą rady miasta na wypadek niedoboru w pokryciu kosztów wystawy zapewnili, a wreszcie niezmordowanemu sekretarzowi komitetu p. Umińskiemu, który w salach wystawy dniem i nocą czuwając, był jakby gospodarzem i stróżem aniołem wystawy ${ }^{44}$.

\section{$* * *$}

Przez pierwsze dwa dni wystawę bezpłatnie mogły zwiedzić tylko osoby posiadające specjalnie wydane na jej otwarcie karty wstępu ${ }^{45}$. Bilet dla jednej osoby, upoważniający do wejścia na ekspozycję, kosztował 30 centów $^{46}$ - cena nie była więc bardzo wysoka ${ }^{47}$. Wystawa w pierwszych dniach od otwarcia cieszyła się tak wielkim

${ }^{42}$ W. Łuszczkiewicz, op. cit., s. 3-4; M. Sokołowski, Wystawa zabytków z czasów Jana III w Sukiennicach krakowskich w roku 1883, s. 3-15; F. Kluczycki, W. Łuszczkiewicz, J. Mycie1ski, I. Polkowski, S. Tomkowicz, P. Umiński, T. Ziemięcki, op. cit., s. 1-2; Odsiecz wiedeńska 1683. Wystawa jubileuszowa..., s. 19-20.

${ }^{43}$ W. Łuszczkiewicz, J. Mycielski, I. Polkowski, P. Umiński, op. cit. ; F. Kluczycki, W. Łuszczkiewicz, J. Mycielski, I. Polkowski, M. Sokołowski, S. Tomkowicz, P. Umiński, T. Ziemięcki, op. cit. Opracowanie to zostało wydane w dwóch edycjach - album z 41 tablicami był wersją rozszerzoną i sprzedawaną od końca V 1884 r. Znajdujące się w nim bezcenne fotografie dokumentujące wystawę wykonał Ignacy Krieger, rysunki zaś przedstawiające wybrane obiekty były dziełami uczniów krakowskiej Szkoły Sztuk Pięknych; Anonim, Album zabytków wieku XVII-go z wystawy jubileuszowej Jana III-go, „Czas”, 29 V 1884, nr 123, s. 3; W. Łu szczkiewicz, op. cit.; M. S okołow ski, Wystawa zabytków z czasów Jana III w Sukiennicach krakowskich w roku 1883; W. B i eńkow sk i, op. cit., s. 110; Odsiecz wiedeńska 1683. Wystawa jubileuszowa ..., s. 19.

${ }^{44}$ W. Łuszczkiewicz, op. cit., s. VII-VIII.

${ }^{45}$ Anonim, Kronika miejscowa i zagraniczna, „Czas”, 11 IX 1883, nr 205, s. 2.

${ }^{46}$ A nonim, Wiadomości artystyczne, literackie i naukowe, „Czas”, 16 X 1883, nr 235, s. 2.

${ }^{47} \mathrm{~W}$ celu porównania: książkę Skarbczyk poezyi polskiej dla ludu i młodzieży można było wówczas nabyć za kwotę 45 centów, a 5 litrów dalmatyńskiego czerwonego wina za 2 zł i 50 centów. Zob. An oni m, 
zainteresowaniem, że podjęto decyzję, zgodnie z którą jednorazowo w salach nie mogło się znajdować więcej niż 50 osób. Jak już wspomniano, w miarę upływu czasu do Krakowa nadal napływały obiekty, a sam Komitet otrzymywał prośby o przedłużenie wystawy. W związku z tym ekspozycja ciągle była uzupełniana, co wskazuje na ogromną elastyczność organizatorów. Pod koniec października podjęto decyzję o przeniesieniu finisażu aż na 18 listopada ${ }^{48}$.

Wystawę zwiedzali przedstawiciele różnych grup ówczesnego społeczeństwa zainteresowani nią byli nie tylko ludzie wywodzący się z rodzin szlacheckich oraz inteligencja, ale także mieszczanie, rzemieślnicy i chłopi ${ }^{49}$. Pod koniec października do Krakowa przybył również dyrektor wiedeńskich archiwów, jeden z głównych organizatorów wystawy w stolicy monarchii - Karl Weiss. Podczas pobytu szczególną uwagę poświęcił wystawie zabytków z czasów Sobieskiego, „której bogactwo podziwiał" "50. Po przyjeździe do Krakowa w połowie listopada ekspozycję obejrzał także ówczesny namiestnik Galicji Filip Zaleski ${ }^{51}$.

O wielkim zainteresowaniu społeczeństwa wystawą świadczy także fragment zamykającego ekspozycję przemówienia Zolla z 18 listopada 1883 roku: „[...] Dowodem tego tyle tysięcy rodaków, którzy po tych salach się przesuwali i na drogich pamiątkach świetnej naszej przeszłości ducha swego krzepili i serce rozgrzewali; dowodem liczny zastęp artystów, którzy bezustannie, z całą gorliwością na przedmiotach wystawionych się kształcili" ${ }^{2}$.

Wystawa była szeroko komentowana na łamach prasy. Przykładowo, w krakowskim „Czasie” ukazały się artykuły Ziemięckiego, w których autor drobiazgowo opisał wiele eksponowanych w Sukiennicach obiektów ${ }^{53}$, opublikowano również teksty Polkowskiego ${ }^{54}$ i Sokołowskiego ${ }^{55}$. W „Przeglądzie Polskim” z kolei można było przeczytać artykuły autorstwa Tomkowicza i Mycielskiego ${ }^{56}$. W obu wymienionych

Tanie wydania J. Chociszewskiego, „Czas”, 28 XI 1883, nr 271, s. 4; Anonim, Dalmatyńskie wino czerwone, „Czas”, 2 XII 1883, nr 275, s. 4.

${ }^{48}$ C. Bąk-Koczarska, op. cit., s. 49-50; Anonim, Wiadomości artystyczne, literackie i naukowe, „Czas”, 25 X 1883, nr 243, s. 3.

49 P. Sierżęga, Obchody 200. rocznicy..., s. 89.

${ }^{50}$ Anonim, Kronika miejscowa i zagraniczna, „Czas”, 24 X 1883, nr 242, s. 2.

${ }_{51}$ Anonim, Kronika miejscowa i zagraniczna, „Czas”, 15 XI 1883, nr 260, s. 2.

${ }_{52}$ A nonim, Przemówienie Dra Zolla, przy zamknięciu Wystawy zabytków z epoki Jana Sobieskiego, „Czas”, 21 XI 1883, nr 265, s. 2.

${ }^{53}$ Artykuły Ziemięckiego pt. Wystawa zabytków z epoki króla Jana III-go i jego wieku zostały zamieszczone na łamach „Czasu” z: 4 X 1883, nr 225, s. 3 ; 5 X 1883, nr 226, s. 3 ; 7 X 1883, nr 228, s. 3; 10 X 1883, nr 230, s. 3; 12 X 1883, nr 232, s. 3; 13 X 1883, nr 233, s. 2; 14 X 1883, nr 234, s. 3-4; 17 X 1883 , nr 236, s. 3.

${ }^{54}$ I. Polkow ski, Sobiesciana. Medale, monety, sztychy, rękopisy, dokumenta, druki (Dokończenie), „Czas”, 23 XI 1883, nr 267, s. 2.

${ }^{55}$ Artykuły Sokołowskiego pt. Wystawa zabytków z czasów Jana III w Sukiennicach krakowskich zamieszczone zostałyna łamach „Czasu” z: 21 X 1883, nr 240, s. 1-2; 15 XI 1883, nr 260, s. 1; 16 XI 1883, nr 261, s. 1; 22 XI 1883, nr 266, s. 1-2.

${ }^{56}$ S. Tomkowicz, J. Mycielski, Wystawa pamiątek i zabytków z epoki Jana III w Krakowie, „Przegląd Polski” 1883, nr XVIII, z. IV. 
czasopismach opublikowane zostały ponadto teksty Ziemięckiego, w których podjął on próbę porównania wystawy krakowskiej z ekspozycją w stolicy monarchii ${ }^{57}$.

Frekwencji wystawy nie sposób niestety określić jednoznacznie i całkowicie pewnie. W „Czasie” z 30 grudnia 1883 roku przeczytać można, że zgodnie ze złożonym na sesji Komitetu sprawozdaniem Kluczyckiego sprzedano łącznie 11079 biletów. Podkreślono jednak przy tym, bez podania przyczyny, że osób „zwiedzających wystawę było o wiele więcej"s8.

Innych bardzo ważnych informacji na temat frekwencji dostarcza kilkukrotnie już cytowane w tekście opracowanie Łuszczkiewicza (napisane niespełna miesiąc po otwarciu ekspozycji - 6 października 1883 r.): ,[...] z różnych państw i z różnych niby to krajów przybyli, a jednak są tu jak u siebie w domu, i pomimo słupów granicznych i dzielnic czują się tutaj czemsiś jednem i niepodzielnem. Siedemnaście tysięcy osób, lekko rachując, przesunęło się po salach wystawy"59.

$* * *$

„Wystawa zabytków z czasów króla Jana III i Jego wieku” była rezultatem ciężkiej i żmudnej pracy wielu osób. Imponowała liczbą zgromadzonych eksponatów, ich różnorodnością, a dla znajdującego się wówczas pod zaborami polskiego społeczeństwa mogła stanowić namacalne świadectwo własnej przeszłości oraz swego rodzaju otuchę na przyszłość.

Zorganizowane w Krakowie w 1883 roku uroczystości dwusetnej rocznicy wiktorii wiedeńskiej miały wysoką rangę, a wernisaż i samo urządzenie wystawy w salach Sukiennic wykorzystano, aby w niezwykle podniosłej atmosferze otworzyć dla społeczeństwa narodowe muzeum.

Co bardzo ważne, bezpośrednim skutkiem ekspozycji (obok równolegle z nią urządzonej wystawy w Langierówce ${ }^{60}$ ) dla „młodej” instytucji był napływ wielu różnorodnych darów. Zgodnie z zapisem Łuszczkiewicza na pierwszej stronie „Inwentarza zbiorów" MNK z lat 1879-1900, w chwili objęcia przez niego posady dyrektora w lipcu 1883 roku, znajdowało się w nim „numerów pierwszych 50 ”61. Na dalszych stronach znaleźć można inny komentarz Łuszczkiewicza, zgodnie z którym tylko w roku 1884 przybyło we wspomnianym inwentarzu numerów $140^{62}$. Na uwagę zasługuje także fakt, że wśród przekazanych do MNK obiektów znajdowały się również te eksponowane na wystawie, na przykład płaskorzeźba marmurowa

${ }^{57}$ T. Ziemięcki, Z wystawy historycznej wiedeńskiej, „Czas”, 23 XI 1883, nr 267, s. 2-3; idem, Z wystawy historycznej wiedeńskiej (Dokończenie), „Czas”, 24 XI 1883, nr 268, s. 2; idem, Wystawa historyczna wiedeńska w zestawieniu z wystawa zabytków z czasów Jana III i jego wieku w Krakowie, „Przegląd Polski” 1883, nr XVIII, z. IV.

${ }_{58}$ Anonim, Kronika miejscowa i zagraniczna, „Czas”, 30 XII 1883, nr 296, s. 2.

${ }^{59}$ W. Łuszczkiewicz, op. cit., s. III-IV.

60 Wystawę tę zwiedziło prawie 1500 osób. Narodziny Muzeum ..., s. 18-21.

${ }^{61}$ Arch. MNK, sygn. 94/10.

${ }^{62}$ Ibidem, s. 36. 
$\mathrm{z}$ wizerunkiem Innocentego XI czy tak zwany pas przeworski (ten ostatni był darem Polkowskiego - członka Komitetu ${ }^{63}$.

Nie udało się natomiast pozyskać do MNK dzieła Matejki Sobieski pod Wiedniem. Obraz ten wystawiany pod koniec sierpnia 1883 roku w Sukiennicach w powszechnym przekonaniu miał trafić właśnie do tejże instytucji. Zgodnie z decyzją samego artysty - która wywołała ogólne poruszenie i została poddana surowej krytyce w prasie - dzieło to przekazano jednak papieżowi Leonowi XIII w grudniu tegoż samego roku ${ }^{64}$.

Ponadto w sprawozdaniu dyrekcji MNK za okres od sierpnia 1883 do lutego 1884 roku można znaleźć zapis, według którego decyzją Komitetu cały zysk z wystawy (nieokreślony z racji trwającej w tym czasie rozprzedaży albumu) został przeznaczony na działalność instytucji, na własność muzeum przeszły także wspomniane w tekście gabloty, szafy czy obicie ścian. W wymienionym sprawozdaniu zawarta jest również opinia Łuszczkiewicza, zgodnie z którą pieniądze z wystawy „winny być użyte na zakupno dzieł sztuki nowożytnej i pokrycie należytości za Gladyatora Panu Welońskiemu"65. Po zamknięciu ekspozycji i jej ostatecznym zdemontowaniu w grudniu 1883 roku krakowskie muzeum cieszyło się dalszym zainteresowaniem ze strony prasy. W „Czasie” często pojawiały się informacje o kolejnych ofiarowanych obiektach $^{66}$, powiadamiano na jego łamach także o rozmaitych działaniach realizowanych przez $\mathrm{MNK}^{67}$.

Dzięki bezpośrednim skutkom wystawy krakowska instytucja zyskała zatem bardzo wiele. Rozwój muzeum, realizacja przyszłych przedsięwzięć i budowa - pomimo podległości państwowej - w najbliższej perspektywie swojej pozycji stały się kwestią otwartą.

${ }^{63}$ Ibidem, nr 64, s. 11, nr 120, s. 22; W. Łuszczkiewicz, J. Mycielski, I. Polkowski, P. Umiński, op. cit., nr 113, s. 18, nr 575, s. 101.

${ }_{64}$ J. Pietrzak, Podarowanie obrazu ,, Sobieski pod Wiedniem” papieżowi Leonowi XIII. Prawda imity, „Acta Universitatis Wratislaviensis” 1990, s. 145-162.

${ }_{65}$ Arch. MNK, sygn. 94/6, Sprawozdania z działalności Muzeum Narodowego w Krakowie (18831888), Sprawozdanie z czynności Dyrekcyi Muzeum Narodowego na czas od VIII 1883 do końca II br., s. 4-9. Nie wiadomo niestety, za jaką kwotę została zakupiona przez MNK rzeźba Gladiator. Arch. MNK, sygn. 94/10, nr 55, s. 9; Galeria Sztuki Polskiej XIX wieku w Sukiennicach, red. B. Ciciora, A. Krypczyk, Kraków 2010, s. 290.

${ }_{66}$ Przykładowo: T. Ziemięcki, Dary do Muzeum Narodowego w Krakowie, „Czas”, 4 XII 1883, nr 276, s. 3; A noni m, Dary do Muzeum Narodowego w Krakowie, „Czas”, 3 I 1884, nr 2, s. 3; A no nim, Dary do Muzeum Narodowego w Krakowie, „Czas”, 25 III 1884, nr 71, s. 3; A no nim, Dary do Muzeum Narodowego w Krakowie, „Czas”, 14 V 1884, nr 111, s. 4.

${ }^{67}$ Przykładowo: Anonim, Kronika miejscowa i zagraniczna, „Czas”, 25 XII 1883, nr 293, s. 2; A nonim, Kronika miejscowa i zagraniczna, „Czas”, 1 III 1884, nr 51, s. 3; A noni m, Kronika miejscowa i zagraniczna, „Czas”, 20 IV 1884, nr 92, s. 3. 


\section{BIBLIOGRAFIA}

\section{Źródła}

\section{Archiwum Muzeum Narodowego w Krakowie}

Kancelaria Dyrektora Władysława Łuszczkiewicza, sygn. 94/6, 94/7, 94/10, 94/16, 94/17, $94 / 18$.

\section{Archiwum Narodowe w Krakowie}

Obchody i uroczystości krakowskie - zbiór szczątków zespołów akt komitetów obchodów, sygn. 29/576/43.

\section{Biblioteka Książąt Czartoryskich w Krakowie}

Władysław Czartoryski. Korespondencja Muzeum. Sprawozdania Zarządu Zbiorów XX Czartoryskich w Krakowie oraz listy w sprawach zbiorów od: Leona Bentkowskiego, Bolesława Biskupskiego, Józefa Łepkowskiego, Stanisława Odrzywolskiego, Mariana Sokołowskiego, sygn. 7312 IV; dawna sygn. Ew. 2149.

\section{Opracowania}

Anonim, Album zabytków wieku XVII-go z wystawy jubileuszowej Jana III-go, „Czas”, 29 V 1884, nr 123, s. 3.

Anonim, Dalmatyńskie wino czerwone, „Czas”, 2 XII 1883, nr 275, s. 4.

Anonim, Dary do Muzeum Narodowego w Krakowie, „Czas”, 3 I 1884, nr 2, s. 3; 25 III 1884, nr 71, s. 3; 14 V 1884, nr 111, s. 4.

Anonim, Dwie wystawy na dwóchsetletni obchód obrony Wiednia, „Czas”, 13 III 1883, nr 58, s. 3.

Anonim, Koronacya cudami wsławionego obrazu Matki Boskiej na Piasku w Krakowie dnia 8 września 1883 roku, dodatek do nru 204 „Czasu”, 9IX 1883, s. 1.

Anonim, Kronika miejscowa i zagraniczna, „Czas”, 11 IX 1883, nr 205, s. 2; 24 X 1883, nr 242, s. 2;27 X 1883, nr 245, s. 3; 15 XI 1883, nr 260, s. 2; 25 XII 1883, nr 293, s. 2; 30 XII 1883, nr 296, s. 2.

Anonim, Kronika miejscowa i zagraniczna, „Czas”, 1 III 1884, nr 51, s. 3; 20 IV 1884, nr 92, s. 3.

Anonim, Program zbiorowy uroczystości dwuchsetnej rocznicy zwycięztwa króla Jana III pod Wiedniem oraz Jubileuszu Matejki, tudzież zjazdu literatów i artystów od d. 11 do d. 16 września 1883 r., dodatek do nru 204 „Czasu”, 9IX 1883, s. 3.

Anonim, Przemówienie Dra Zolla, przy zamknięciu Wystawy zabytków z epoki Jana Sobieskiego, „Czas”, 21 XI 1883, nr 265, s. 2.

Anonim, Rozmaitości z literatury, sztuki i życia społecznego, „Tygodnik Illustrowany”, 1 XII 1883, nr 48, s. 361. 
Anonim, Schluss der historischen Ausstellung, „Neue Freie Presse”, 5 XI 1883, nr 6894, s. 1.

Anonim, Sobiesciana, „Czas”, 31 III 1883, nr 73, s. 2; 12 IV 1883, nr 82, s. 2; 20 IV 1883, nr 89 , s. 2-3; 10 V 1883, nr 104, s. 4; 20 V 1883, nr 112, s. 3; 1 VI 1883, nr 121, s. 3; 21 VI 1883 , nr 138, s. 2; 29 VI 1883, nr 145, s. 2-3; 15 VII 1883, nr 158, s. 2; 26 VII 1883 , nr 167, s. 3; 4 VIII 1883, nr 175, s. 2; 10 VIII 1883, nr 180, s. 3; 28 VIII 1883, nr 194, s. 3.

Anonim, Tanie wydania J. Chociszewskiego, „Czas”, 28 XI 1883, nr 271, s. 4.

Anonim, Uroczystości krakowskie, „Gazeta Lwowska”, 12 IX 1883, nr 208, s. 2-3.

Anonim, Uroczystość dwuchsetletniej rocznicy zwycięstwa Jana III pod Wiedniem, „Czas”, 12 IX 1883, nr 206, s. 2-3.

Anonim, Wiadomości artystyczne, literackie i naukowe, „Czas”, 16 X 1883, nr 235, s. 2; 25 X 1883, nr 243, s. 3; 30 X 1883, nr 247, s. 3; 14 XI 1883, nr 259, s. 2.

Bąk-Koczarska C., Rada miejska organizatorem obchodu 200-lecia odsieczy Wiednia w Krakowie, „Krzysztofory. Zeszyty Naukowe Muzeum Historycznego Miasta Krakowa" 1982, z. 9.

Bieniarzówna J., Małecki J.M., Dzieje Krakowa. Kraków w latach 1796-1918, Kraków 1979.

Bieńkowski W., Rok 1883 w Krakowie (Uroczystości 200-lecia odsieczy Wiednia), „Rocznik Krakowski” 1987.

Błońska D., Mróz S.A., Na przełomie starych i nowych czasów. Muzeum Narodowe w Krakowie w latach 1900-1901, „Res Gestae. Czasopismo Historyczne” 2016, t. 3.

Chodubski A., Sierakowski Adam (1846-1912), PSB, t. XXXVII, Warszawa-Kraków 1996-1997, s. 254-255.

Galeria Sztuki Polskiej XIX wieku w Sukiennicach, red. B. Ciciora, A. Krypczyk, Kraków 2010.

Dybiec J., Stanisław Tarnowski - autorytet, polityk, uczony (głos w dyskusji), Kraków 1999.

Galos A., Obchody rocznicy odsieczy wiedeńskiej w Galicji w 1883 r., „Acta Universitatis Wratislaviensis"1990.

Józefa Czecha Kalendarz Krakowski na rok 1884, Kraków 1884.

Kluczycki F., Łuszczkiewicz W., Mycielski J., Polkowski I., Sokołowski M., Tomkowicz S., Umiński P., Ziemięcki T., Zabytki XVII wieku. Wystawa jubileuszowa Jana III w Krakowie 1883, Kraków 1884.

Kłobukowski A., Przyp. red., „Czas”, 21 XI 1883, nr 265, s. 2.

Kosicka-Pajewska A., Zachowawcza myśl polityczna w Galicji w latach 1864-1914, Poznań 2002.

Łazuga W., Ostatni stańczyk. Michał Bobrzyński - portret konserwatysty, Toruń 2005.

Łoski J., Jan Sobieski, jego rodzina, towarzysze broni $i$ współczesne zabytki, Warszawa 1883.

Łuszczkiewicz W., Z wystawy starożytności z czasów Sobieskiego w Sukiennicach. Wrażenia i uwagi, Kraków 1883.

Łuszczkiewicz W., Mycielski J., Polkowski I., Umiński P., Katalog wystawy zabytków z czasów króla Jana III i Jego wieku, Kraków 1883.

Narodziny Muzeum. Ważniejsze daty w stuletnich dziejach Muzeum Narodowego w Krakowie, red. F. Stolot, Kraków 1979.

Nowolecki A., Na pamiątkę 200-letniej rocznicy odsieczy Wiednia 1683 r. Uroczystości ku uczczeniu pamięci Jana III w ziemiach polskich i za granica, Kraków 1883. 
Odsiecz wiedeńska 1683. Wystawa jubileuszowa w Zamku Królewskim na Wawelu w trzechsetlecie bitwy. Tło historyczne i materiały źródłowe, red. A. Franaszek, K. Kuczman, t. I, Kraków 1990.

Olszański K., Juliusz Kossak, Kraków 2000.

Pietrzak J., Podarowanie obrazu „, Sobieski pod Wiedniem” papieżowi Leonowi XIII. Prawda i mity, „Acta Universitatis Wratislaviensis” 1990.

Pijaj S., Między polskim patriotyzmem a habsburskim lojalizmem. Polacy wobec przemian ustrojowych monarchii habsburskiej (1866-1871), Kraków 2003.

Polkowski I., Sobiesciana, „Czas”, 13 VII 1883, nr 156, s. 2-3.

Polkowski I., Sobiesciana. Medale, monety, sztychy, rękopisy, dokumenta, druki (Dokończenie), „Czas”, 23 XI 1883, nr 267, s. 2.

Rożek M., Tradycja wiedeńska w Krakowie, Kraków 1983.

Rożek M., Zwycięstwo Jana III Sobieskiego pod Wiedniem. Echa wiktorii, Kraków 2008.

Sierżęga P., Centralny Komitet Jubileuszowy w przygotowaniach obchodów 200. rocznicy odsieczy wiedeńskiej w Galicji [w:] Z przeszłości Europy Środkowowschodniej, red. J. Hoff, Rzeszów 2002.

Sierżęga P., Obchody 200. rocznicy odsieczy wiedeńskiej w Galicji (1883 r.), Rzeszów 2002.

Sokołow ski M., Wystawa zabytków z czasów Jana III w Sukiennicach krakowskich, „Czas”, 21 X 1883, nr 240, s. 1-2; 15 XI 1883, nr 260, s. 1; 16 XI 1883, nr 261, s. 1; 22 XI 1883, nr 266, s. 1-2.

Sokołowski M., Wystawa zabytków z czasów Jana III w Sukiennicach krakowskich w roku 1883, Kraków 1884.

Tomkowicz S., Mycielski J., Wystawa pamiątek i zabytków z epoki Jana III w Krakowie, „Przegląd Polski” 1883, nr XVIII, z. IV.

Walicki M., Rembrandt w Polsce, „Biuletyn Historii Sztuki”1956, R. XVIII, nr 3.

Weigel F., Wystawa zabytków z epoki Sobieskiego w Krakowie 1883 r., „Czas”, 2 VIII 1883, nr 173, s. 2.

Ziemięcki T., Dary do Muzeum Narodowego w Krakowie, „Czas”, 4 XII 1883, nr 276, s. 3.

Ziemięcki T., Wystawa historyczna wiedeńska w zestawieniu z wystawa zabytków z czasów Jana III i jego wieku w Krakowie, „Przegląd Polski” 1883, nr XVIII, z. IV.

Ziemięcki T., Wystawa zabytków z epoki króla Jana III-go i jego wieku, „Czas”, 4 X 1883, nr 225, s. 3; 5 X 1883, nr 226, s. 3; 7 X 1883, nr 228, s. 3; 10 X 1883, nr 230, s. 3; 12 X 1883, nr 232, s. 3; 13 X 1883, nr 233, s. 2; 14 X 1883, nr 234, s. 3-4; 17 X 1883, nr 236, s. 3.

Ziemięcki T., Z wystawy historycznej wiedeńskiej, „Czas”, 23 XI 1883, nr 267, s. 2-3.

Ziemięcki T., Z wystawy historycznej wiedeńskiej (Dokończenie), „Czas”, 24 XI 1883, nr 268, s. 2.

Zoll F., Sobiesciana, „Czas”, 10 VII 1883, nr 153, s. 3; 24 VII 1883, nr 165, s. 3; 1 VIII 1883, nr 172, s. 3.

Zych E., Ks. Teofil Midowicz. Od wikariusza katedralnego do kustosza Kapituły. 40 lat dziatalności dla miasta i Kościoła krakowskiego [w:] Klejnot w koronie. 650-lecie konsekracji katedry krakowskiej, red. J. Urban, E. Zych, Kraków 2017. 